مجلة العلوم التربوية والإنسانية

Journal of Educational and Human Sciences

www.jeahs.com

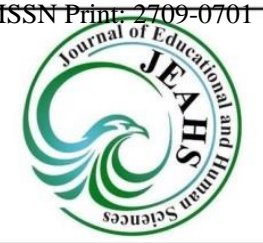

\title{
The Inclusion of Life Skills in Secondary School English Textbooks in Saudi Arabia
}

\author{
Dr. Thuraya Al Jar \\ Assistant Professor, Curriculum and Instruction \\ Faculty of Education \\ Shaqra University \\ Saudi Arabia \\ Email: thaljaar@su.edu.sa
}

\begin{abstract}
The ultimate goal of education is to enable people from life skills which help them to fitting for living in $21^{\text {st }}$ century. Therefore, infusing life skills within the materials of the school curricula such as English student's textbook is an important issue to fulfill such goal. Yet, the purpose of this study was to find out the life skills in the content of the Saudi Student's Secondary School English Textbooks according to an inventory of the life skills which is developed by the researcher herself. To this end, an Inventory of the life skills, and a checklist of content analysis were developed and conducted to a sample consisted of 73 reading texts which were selected from a population consisted of the Saudi Student's Secondary School English Textbooks for the $4^{\text {th }}$ grade up to the $6^{\text {th }}$-grade (i.e. MGSs). Results of the study revealed that a total of (70) life skills, distributed among (10) main categories (MCs) and (25) sub-categories (SCs), were found as a result of the completely consensus among the panel of experts. Also the results revealed that all life skills of the supposed inventory were included within the analyzed textbooks. Yet, the distribution of these skills was somehow unbalanced and insufficient. Based on the study's results some recommendations were recommended.
\end{abstract}

Keywords: Life Skills, Content Analysis, English reading textbook, Secondary school. 


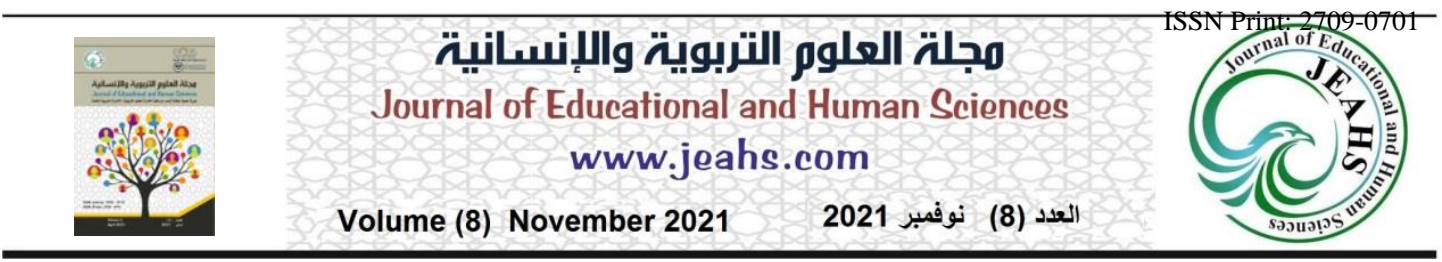

\section{Introduction}

Nowadays, life skills (e.g. Decision making, Problem Solving, Creative Thinking, etc.) become an urgent necessity for living in $21^{\text {st }}$ century. Life skills are the abilities that enable individuals from adapting their behavior into a good and a positive behavior during their daily live (Panduranga, et al., 2018, p. 838; Al-Masri, et al., 2016, p. 82; Strikala \& Kishore, 2010, p. 345; Khosravani et al., 2014, p. 57; WHO, 1997, p. 1). Moreover, life skills are skills that assist promote basic well-being and competences in student, as a younger citizen, as he faces his reality of life. Therefore, students should be exposed to the life skills via the material of the education curricula, including the material of the English language curriculum, in the different educational stages.

English reading textbooks are one of the effectiveness materials of such curriculum. They serve as a tool of teaching and learning for both teachers and students. Over the world, teachers (i.e. English teachers), use textbooks to guide their instruction. So textbooks greatly influence how content is delivered. Besides, textbook such as English textbook is important material of the English curriculum since it is the core of educational process, and is a source of teaching and learning English. In addition, there are some calls to activate the life skills as vital important skills in the educational school curricula, mainly English curricula (Gayatri et al., 2017, p. 2; Lagat, 2017; MOE, 2018). Therefore, this study is an attempt to find out these skills in the Saudi Student's Secondary School English reading texts via analyzing the life skills in such textbooks.

\section{Statement of the Problem}

Due to Saudi Vision 2030, Saudi Arabia is moving into many directions to enhance the quality of life to all citizens and youths in particular, and to provide them with life skills that enable them to keep peace with the developed world. This is a big challenge that requires an immediate and an effective response from the Ministry of Education. In fact, life skills are taught as a compulsory subject in the Saudi secondary school curriculum in order to enable students effectively with the demands and challenges of everyday life. Yet such skills are very needed to be integrated in each textbook, including English textbooks since they are the most effective skills which are mainly addressed to the benefit of Saudi dynamic youth. Accordingly, it is essential to analyze Saudi Student's Secondary School English Textbooks, MegaGoal Series (MGSs), to find out the distribution of these skills in the English textbooks and see if it is sufficient or not. Moreover, analyzing such textbooks in terms of the inventory's life skills helps in determination the best English-reading textbooks for learningteaching English subject for Saudi Student's Secondary Schools. 


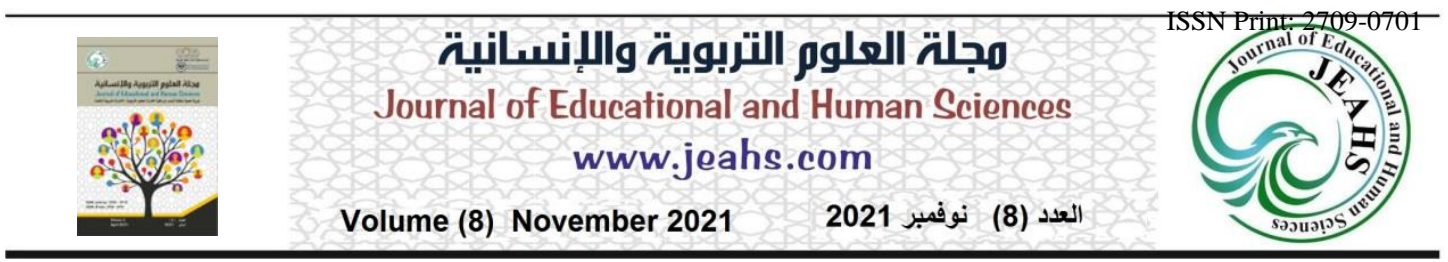

\section{Purpose and Aims of the Study}

The purpose of this study is to find out the Life Skills in the content of the Saudi Student's Secondary School English Textbooks for the 4th-grade up to the 6th-grade. In detail, the aims of this study are to:

3.1. develop a valid and reliable life skills inventory as a proposed inventory for including the life skills in the content of the Saudi Student's Secondary School English Textbooks (i.e. MGSs);

3.2. find out whether the life skills were included in the analyzed textbooks (i.e. In Saudi Student's Secondary School English Textbooks), according to the inventory's life skills;

3.3. compare life skills within the analyzed textbooks with each other.

\section{Questions of the Study}

To carry out the aims of the study, researcher attempted to answer the following questions:

4.1. What are the life skills that supposed be included in the content of the Saudi Student's Secondary School English Textbooks?

4.2. What are the included life skills in the Saudi Student's Secondary School English Textbooks for the $4^{\text {th }}$ up to the 6th-grades in terms of the inventory's life skills?

4.3. Are there any differences between the analyzed textbooks in terms of the supposed inventory?

\section{Terms Definitions}

Three important terms (life skills, textbook, and secondary school) were mentioned. As for the term of life skills, there is no certain list or classification of life skills, as they amend in importance and priority according to life situation, culture, norms, age or position. Life skills are aboard concept and cannot be defined in one specific category as functioning effectively (Bailey \& Deen, 2002, p.10).

\subsection{Life Skills}

Definition of the life skills refers to a broad range of soft skills which often vary depending on our individual situations. For young learners, life skills might include numeric literacy and understanding how to share with others, while for university students, might include knowing how to manage different workloads and meet necessary deadlines. life skills: According to World Health Organization (WHO) (1997, p.1) "life skills are abilities for adaptive and positive behavior that enable individuals to deal effectively with the demands and challenges of everyday life" (https://www.holychildpublicschool.in/h/lyf_skill.php). According to United Nations Children's Fund (UNICEF) (2019, p. 7) life skills are a set of abilities, attitudes and socio-emotional competencies that enable individuals to learn, make informed decisions and exercise rights to lead a healthy and 


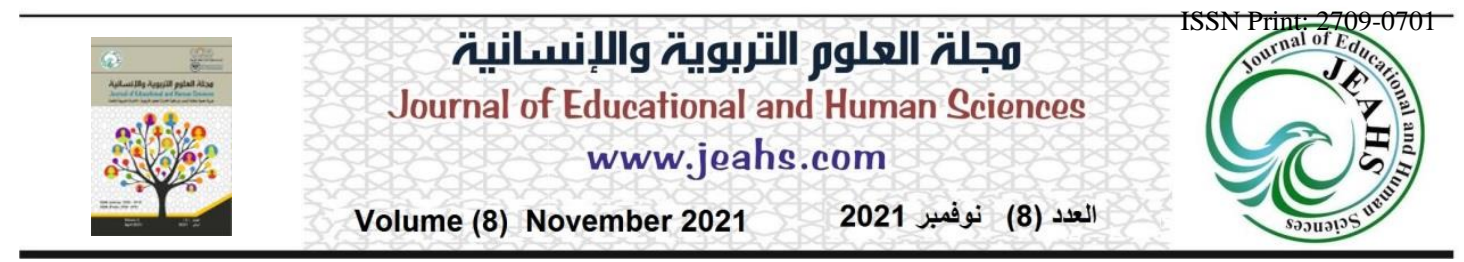

productive life and subsequently become agents of change.

\subsection{Core/ Categories of Life Skills}

World Health Organization (1997, p. 2) laid down ten core life skills which were taken in consideration as the MCs of life skills for the content analysis's instrument of this study. These skills are:

1. Self-awareness: includes recognition of oneself, character, strengths and weaknesses, one's desires and dislikes.

2. Empathy: means the ability to imagine what life is like for another person, even in a situation that one might not be familiar with.

3. Critical thinking: means the ability to analyze information and experiences in an objective manner.

4. Creative thinking: means the ability to explore the available alternatives and various consequences of one's actions.

5. Decision-making: means the ability to deal constructively with decisions about one's life.

6. Problem solving: means the ability to look at any problem objectively vis-à-vis the different options for solutions and would help one comes to a solution after weighing the pros and cons of the different options available.

7. Effective communication: means one's ability to express himself, his opinions, desires, needs and fears both verbally and nonverbally, in ways that are appropriate to cultures and situations. It also includes the ability of being able to ask for advice and help in a time of need.

8. Interpersonal relationship: means one's ability to relate in positive ways with people he interacts with in his everyday life. It includes his ability to make and keep friendly relationships, maintain good relations with family member and ability to end relationships.

9. Coping with stress: means recognizing the sources of stress in one's life, recognizing how this affects him, and acting in ways that help him control his levels of stress by changing physical environment or lifestyle, and learning how to relax.

10. Coping with emotions: means recognizing emotions within oneself and others, being aware of how emotions influence behavior, and being able to respond to emotions appropriately.it includes learning to manage intense emotions like anger or sadness.

\subsection{Operational Definition of Life Skills Term}

For this study, life skills (LS) can be defined operationally as the availability of life skills with the ten categories of the inventory's life skills (i.e. decision-making, problem solving, creative thinking, critical thinking, effective communication, interpersonal relationship skills, self-awareness, empathy, coping with emotions, coping with stress) that should be included in the Saudi Student's Secondary School English Textbooks for the $4^{\text {th }}$-grade up to the $6^{\text {th }}$-grade. 


\section{مجلة العلوم التربوية والإنسانية}

Journal of Educational and Human Sciences

www.jeahs.com

Volume (8) November 2021

العدد (8) نوفمبر 2021

\subsection{Definition of Textbook}

Regarding the textbooks, textbooks are defined as the books which were written for the teaching-learning's purpose (Okeefee, 2013, p. 3). Referring to Instructional Services Textbook Adoptions Office, textbook defines as

"Textbook means systematically organized material comprehensive enough to cover the primary objectives outlined in the Standard Course of Study for a grade or course. Formats for textbooks may be printed or non-printed, including hardbound books, softbound books, activity-oriented programs, classroom kits, and technology-based programs that require the use of electronic equipment in order to be used in the learning process (2004, p.5).

\subsection{Operational Definition of Textbook}

Operationally, for this study, textbook (i.e. MGSs) is a series of six student's English read textbooks for the $4^{\text {th }}$ up to the $6^{\text {th }}$ grades, $3^{\text {rd }}$ edition, which published by McGraw-Hill Education and prescribed by Saudi Ministry of Education for secondary school students, Credits System. Each level in MGSs has Student textbook, Audio Program, Workbook, Teacher's Guide and EZ Test CD-ROM with Test Generator, and which supposed included life skills.

\subsection{Definition of Secondary School}

In Saudi Arabia, Secondary School lasts three years and it is the final stage of general education. Usually, the age of secondary school student is from (15-18) years old.

\section{Limitations of the Study}

This study was limited only to the life skills of the developed inventory skills which prepared by this study; the textbooks of MGSs of the Saudi Student's Secondary School English Textbooks for the $4^{\text {th }}$-grade up to the $6^{\text {th }}$-grade; as well as the academic year of $1442 \mathrm{~h}$. Yet, results of this study will be restricted to the limitations mentioned earlier.

\section{Related Background}

The ultimate goal of education is to fit students for their future life. Secondary schooling is a key link between primary and higher education. It plays a vital role in developing an effective personality in one's life. It is, thus, one of the most important stage for every student as a future citizen, over the world. Yet, it is the responsibility of all (i.e. parents, teachers, principals and other stakeholders) to guide students and work dedicatedly to develop their ability, interest and attitude towards life. Therefore, including 


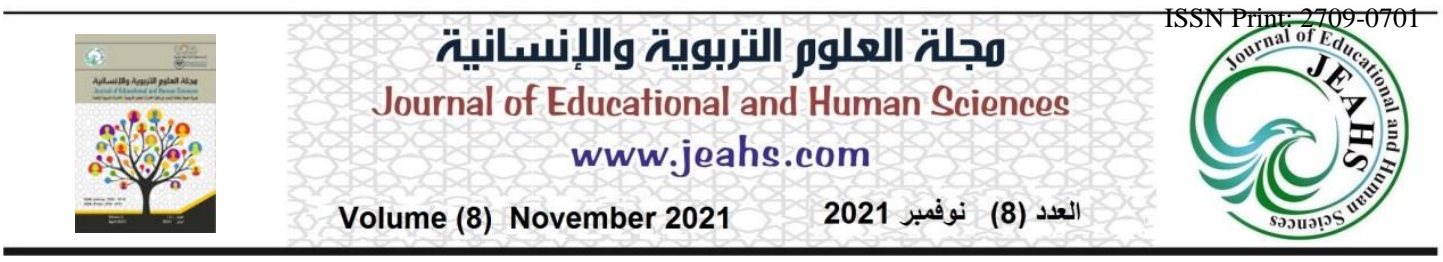

LSs within the secondary school curricula, such as English curriculum, should be an inseparable of school curriculum. Education of life skills should be the cornerstone of various adolescence programmers and an integral part of formal education process (Hamodona, 2007; Aparna \& Raakhee, 2011, p. 3-5; Al-Masri, et. al., 2016, p. 83). It has become now a global trend and it is regarded as integral to preparing young people to interfere everyday challenges and risks and enhance their productive participation in society.

Many benefits can be gained by compilation of education of life skills with school education. For instance, it can help students to build a good personality and strengthen their knowledge in all settings to generate an effective future (1); it provides students with strategies to make healthy choices that contribute to a meaningful life and helps them to take positive actions to protect themselves and to promote healthy and meaningful social relationship (2); promote mental well-being and develop competences to face realities of life (3); enables them to develop concept of oneself as a person of worth and dignity and to translate knowledge, attitude, skills and values into action (4); enables them to explore alternatives, weigh pros and cons and make rational decisions in solving each problem or issue as it arises (5); entails being able to establish productive interpersonal relationships with others (6); d helps them in translating knowledge, attitude and values into healthy behavior that makes their life fruitful (WHO, 2020, p. 18; Gayatri et al., 2017, p. 19-29; Lagat, 2017, p. 86-87; Sing \& Gera, 2015, p. 760; Sing \& Sing, 2014, p. 23; Munsi \& Guha, 2014, p. 93; Kumar \& Chhabra, 2014, p. 187; Aparna \& Raakhee, 2011, p. 3-5).

There are two approaches to infuse LSs in the school curricula: integration approach, augmentation approach, and separated subject approach (Giri \& Sharma, 2016, p. 6; Mugami \& Muthi, 2013, p.5). In 'integration' approach, life skills topics are integrated into other subjects taught by different teachers, while in 'separate subject' approach, all concepts of life skills are combined into one subject and taught by a specialized teacher. Life skills can be integrated to all elements of teaching: materials, methods, media, measures and management. Sometimes, the infusion approach is preferred over augmentation approach because, as Mostafa et al., stated

"it is likely suitable for developing life skills through any curriculum and at the same time adds no burdens on the academic plan, nor needs any extra subjects to teach, extra classes to attend or extra exams to take.". (2016, p. 51)

In Saudi Arabia, life skills have been given a great emphasis. They are taught as a compulsory subject at the secondary school which was 


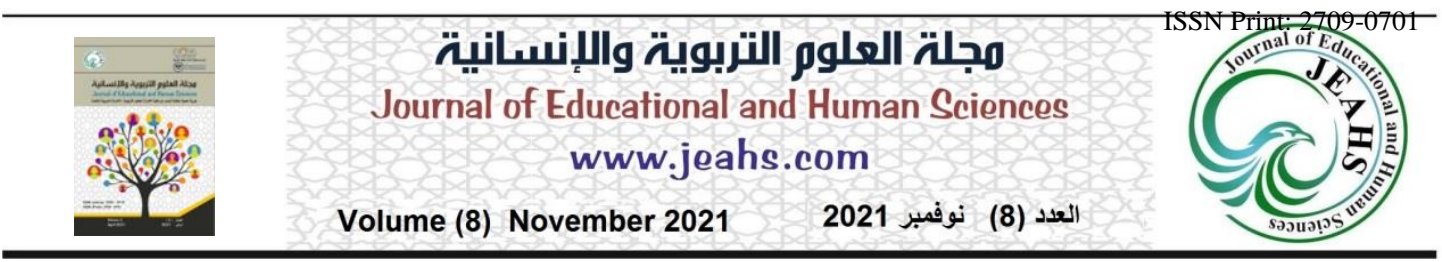

introduced on the year 2018s by Ministry of Education (MOE, 2018) with an aim of equipping Saudi Secondary School with adaptive and positive behavior that would enable students effectively with the demands and challenges of everyday life. Besides, it ensures sustainable attempts to design textbooks for different courses according to the requirements of the time, and to follow vast strategies of integrating subject knowledge of different subjects with life skills as to transmit the integrated subject matter to all students, especially the adolescent group. Life skills are one of the governing variables and factors responsible for the successful, healthy and balanced life along with the subject knowledge in a particular field (Al-Masri, et. al., 2016, p. 84).

Regarding education of English language, in Saudi Arabia, English is also taught as a compulsory foreign language in all public and private Saudi primary, intermediate and secondary school to develop Saudi students with the four English language skills and psychomotor, social, cognitive and social domains. English language curriculum is designed by local and multinational English experts under the supervision of MOE with the ultimate goal of enabling students to communicate and use the target in real life situations (Alshumaimeri, 2015, p. 230). As for secondary schools, in their intents to prepare Saudi secondary school to become global citizens, Saudi policies aim to gradually naturalize English in Saudi Arabia to absorb cultural, religious and social values and beliefs (Al-Tamimi, 2019, p. 68). Moreover, MOE makes tremendous efforts to improve educational outcomes and enable students to get benefits from school textbooks as much as possible, since English textbooks are considered the most relevant source of learning and teaching materials of accompanying package such as students' textbook, workbook and class CDs (Allehyani, Burnapp, \& Wilson, 2017, p.13). It is MOE authorities only introduce and distribute English textbooks among schools equally.

In the context of infusing life skills in English language curriculum, integration of life skills tends to develop communicative competence on the part of English language learners. The acquisition of life skills occurs simultaneously with that of language skills. In this case, learning materials (content) are selected to reflect the targeted life skills (Sajid, Saleh \& Retmono, 2013, p.76). English classes textbooks should focus on how to enhance cognitive skills, social skills, human skills and coping skills through life skills education which will help $21^{\text {st }}$ century youth to achieve their goals, strengthen their abilities to meet the demands of the present society and lead a satisfying life (Panduranga, et, al. 2019, p. 838).

\section{Related Literature}

As a relevant literature deals with life skills, several studies have been 


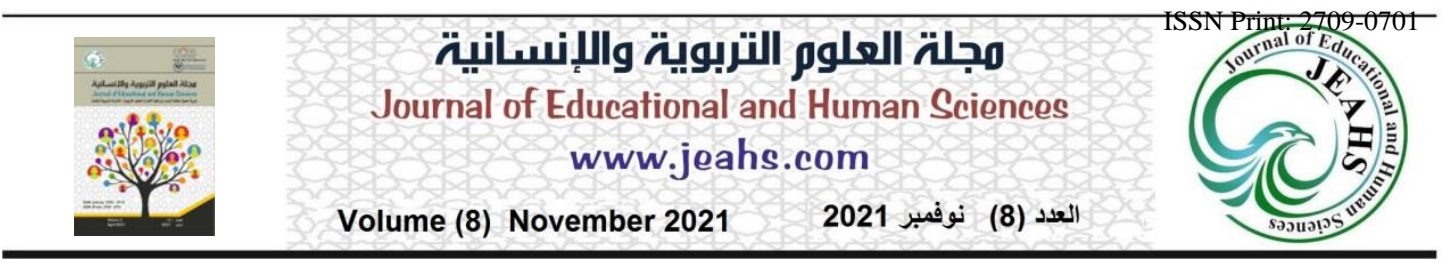

conducted in different places over the world by different methods for collecting data, i.e. analytical studies, explosion studies etc., (e.g. Khosravani, et al., 2014, p. 200-207; Sing and Sing, 2014; Mostafa et al., 2016, p. 43-62; Ashraf et all., 2017; Al-Mamary, 2018; Rakhmawati and Priyana, 2019; Rinekso, 2021). Moreover, a considerable number of studies has focused on finding out the life skills in different student's textbooks including English student's textbooks.

For instance, Rinekso (2021) conducted a case analysis study aimed to analyze the representation of $21^{\text {st }}$ century skills in an Indonesian EFL of the $7^{\text {th }}$-grade's English student textbook. To fulfil this aim, he used a framework that provides detail descriptions of the $21^{\text {st }}$ Century Skills, as an instrument for analyzing these skills in the analyzed textbook. Results of the study revealed that (12 out of 15$)$ of the $21^{\text {st }}$ Century Skills were included in this textbook. Also, results revealed that most dominant skills found in the textbook were communication and collaboration. Skills of information, communication, and technology were insufficiently included in this textbook.

Similarly, Rakhmawati and Priyana (2019) conducted a study aimed to find out the integrated $21^{\text {st }}$ Century Skills in English textbook used in senior high school. To this end, the researcher developed a checklist of content analysis for analyzing each of $21^{\text {st }}$ Century Skills and instruction strategies in the analyzed English textbook. As for $21^{\text {st }}$ Century Skills, results of the study showed that (11) $21^{\text {st }}$ Century Skills (i.e. critical thinking and problem solving, communication, collaboration, creativity and innovation, information and communication technology, media literacy, leadership and responsibility, productivity and accountability, social and cross-cultural, initiative and self-direction, and flexibility and adaptability) were integrated in this textbook.

In the same context of finding out life skills within English textbooks content, one of Abu Saib and Al-Hadidi (2018) study's aims was to identify the availability the included life skills in the English text book's content of the $6^{\text {th }}$-Basic grade in Amman. To achieve such aim, researchers developed a content analysis checklist that used for analyzing the content of this textbook. Regarding to content analysis's results, it was revealed that high availability of mental skills was included in the analyzed textbook, whereas low availability of social skills was found in the same textbook.

Another study conducted by Ashraf et al., (2017) aimed to examine the ELT teachers' attitudes towards life skills latent in Iranian EFL textbooks junior secondary program. To the end, a mixed--research approach (i.e. quantitative and qualitative research approach) was used. Specifically, a questionnaire, as a quantitative research method, was distributed among a 


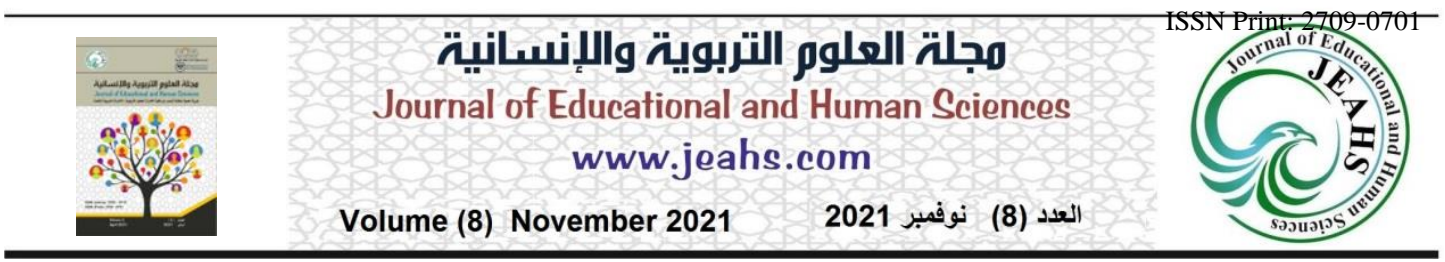

sample consisted of 31 of ELT teachers. On the other hand, (13) interviews, as a qualitative research method, were also carried out with the same teachers on the detailed reasons and evidence of their answers. Results of this study revealed that Iranian EFL textbooks improved most of the EFL learners' essential life skills and teachers have a positive attitude towards these skills. They also presented some helpful suggestions for improving the textbooks regarding such skills.

In addition, a relative study to the context of finding out life skills within English textbooks content, Al-Masri et al., (2016) fulfilled a study aimed to analyzing Action Pack English textbooks' text based on the availability of life skills in Jordan and to determine their frequencies and percentages of life skills present in each text. The sample of the study was English language textbooks for Action Pack Series for the 5th-grade up to the 6th-grade. The study dealt with only (10) life skills. Findings of the study indicated that life skills are randomly distributed among the three English Action Pack textbooks. The highest percentage was for effective communication life, followed by problem solving life skill. Relying on the results, the study suggested developing appropriate criteria for the distribution of life skills in the English textbooks.

Also, Mostafa et al., (2016) performed a study aimed to evaluate the included life skills in the English curriculum of primary school. The researchers developed a content analysis instrument for analyzing a sample of the 4th-grade English textbooks including textbook of life skills. Results of this study revealed that the included life skills in the analyzed curriculum (i.e. curriculum of the $4^{\text {th }}$-grade English primary school) were insufficient. Based on its results, this study presented a suggested framework for developing the evaluated curriculum based on the consisted life skills of the developed content analysis instrument.

Likewise, one aim of Bouzid study's aims (2016) was to find out the included skills of the 21 st century among a sample (i.e. three Moroccan ELT textbooks) of ELT textbooks which were taught to the 2nd-year Baccalaureate students in public high school. Also this study aimed to determine the activities which are more sufficient for promoting such skills. As for the content analysis results, results showed that very little activities of the analyzed textbooks which enable learners to develop their ICT skills and they do not encourage learners to think creatively and develop career and life-skills.

Another study conducted by Khosravani et al., (2016) aimed at assessing the range of the integrated life skills to the Iranian EFL textbooks. 


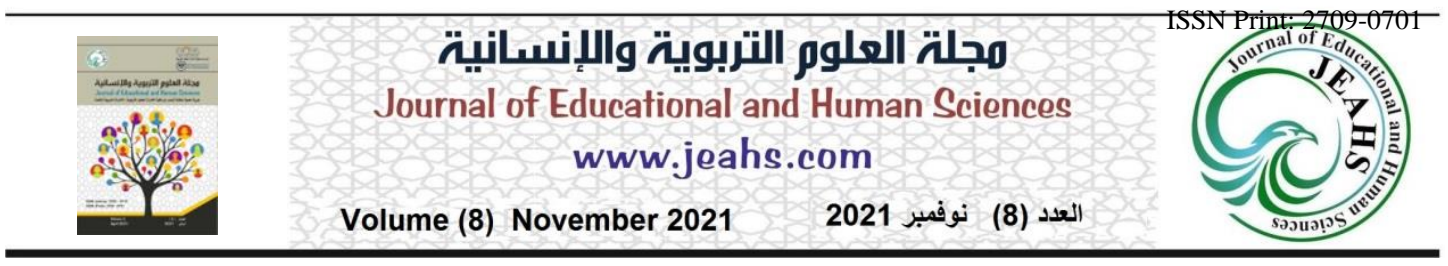

To fulfill this aim, researchers utilized a modified life skills questionnaire consisted of a one open-ended question as well as a structured questionnaire which consisted of 58 items. Both of the questionnaires were distributed among (73) ELT teachers and (1112) EFL junior and senior high school learners almost all over Iran. The study results showed that Iranian EFL textbooks do not improve the EFL learners' essential life skills especially the life skills of leadership, critical thinking, decision making, and problem solving.

In the same context of analyzing English student's textbook, Sing and Sing (2014) analyzed both: The Hindi English text books of class IX U.P. and the English Text books of class IX U.P., in light of life skills. The study adapted a type of CAS for which descriptive survey method used to take the opinion of the subject teachers. The study's result showed that the English text books of U.P. Board were found rich enough life skills content. While most of the life skills were moderately included and in the analyzed textbook, some of them were substantially included. In contrast, the Hindi Text book of U.P. Board was found much rich in the life skills content. Most of life skills were substantially included and some were moderately included.

\section{Methodology}

This study is a content analysis study which belongs to the descriptive research approach. Content analysis is a research method for subjective interoperation of content of text data through systematic classification process of coding and identifying themes or patterns (Hsieh \& Shannon, 2005 , p. 1278). To carry out this study content analysis was used because its suitability for the purpose of the study (i.e. investigating the included life skills in the English MGSs Series texts books for Saudi public secondary school).

\section{1. Population and Sample of the Study}

Seventy-three reading texts, as a sample of this study, were selected to fulfil this study. Reading texts were chosen from a population consisted of the Saudi Student's Secondary School English Textbooks for the $4^{\text {th }}$-grade up to $6^{\text {th }}$ - grade (i.e. MGSs). Moreover, reading texts were selected from 18 units, 6 units for each textbook. Table (1). illustrates the distribution sample's items among the units of the analyzed text books (i.e. the $4^{\text {th }}, 5^{\text {th }}$, and $6^{\text {th }}$ English textbooks of MGSs). 


\section{مجلة العلوم التربوية والإنسانية}

Journal of Educational and Human Sciences

www.jeahs.com

Volume (8) November 2021

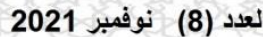

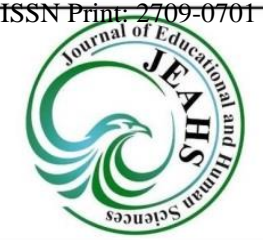

Table 1. distribution sample's items among the units of the Saudi Student's Secondary School Reading Texts in English Textbooks-MGSs

\begin{tabular}{|c|c|c|c|c|c|c|c|}
\hline Grade & Unit 1 & Unit 2 & Unit 3 & Unit 4 & Unit 5 & Unit 6 & Total \\
\hline $4^{\text {th }}$ & 4 & 3 & 5 & 4 & 4 & 4 & 24 \\
\hline $5^{\text {th }}$ & 4 & 3 & 5 & 4 & 4 & 5 & 25 \\
\hline $6^{\text {th }}$ & 4 & 4 & 5 & 3 & 3 & 5 & 24 \\
\hline \multicolumn{7}{|c|}{ Total } \\
\hline
\end{tabular}

\subsection{Instrument of the Study}

As regard to the study's instrument, researcher developed an inventory of the life skills. To develop this inventory, researcher achieved a survey of the related material (i.e. studies, books, websites etc.). For instance, the studies of (Sing and Sing, 2014; Mostafa et al., 2016; Al-Mamary, 2018:; Rakhmawati and Priyana, 2019; Rinekso, 2021) were analyzed. Then the primary version of the inventory was sent to six panel of experts in order to validate it. Therefore, completely consensus of the experts was taken as a criterion to accept life skills as an item of the inventory. The inventory consisted of (70) life skills distributed on (25) Sub-categories (SCs), which distributed on (10) Main Categories (MCs) as it is showed in table (2).

Table 2. Distribution LSs among MCs and SCs of Content Analysis Instrument

\begin{tabular}{|c|c|c|c|}
\cline { 2 - 4 } \multicolumn{1}{c|}{} & Main Category & Sub-category & LS \\
\hline 1 & Decision making & 2 & 6 \\
\hline 2 & Problem Solving & 2 & 7 \\
\hline 3 & Creative Thinking & 4 & 10 \\
\hline 4 & Critical Thinking & 3 & 8 \\
\hline 5 & Effective Communication & 2 & 8 \\
\hline 6 & Social and Interpersonal Relationship & 2 & 7 \\
\hline 7 & Self-awareness & 4 & 11 \\
\hline 8 & Empathy & 2 & 5 \\
\hline 9 & Coping with Emotions & 2 & 4 \\
\hline 10 & Coping with Stress & 2 & 4 \\
\hline & Total & 25 & 70 \\
\hline
\end{tabular}

As to the reliability of the instrument, using check list of life skills, two different raters analyzed the selected reading texts (i.e. sample) in terms of the identified rules of analysis. Then percentage of agreement between the two rates was calculated, as an inter-rater rat, using Cooper's Equation (i.e. Ratio Agreement $=$ number of agreed answers/ (number of greed answers + number of disagreed answers) $X 100 \%)$. Results of the inter-rater rat was found $(87 \%-92 \%)$, as it is shown in table (3). 


\section{مجلة العلوم التربوية والإنسانية}

Journal of Educational and Human Sciences

www.jeahs.com

Volume (8) November 2021

العدد (8) (8)

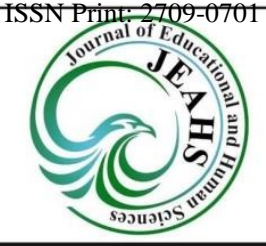

Table 3. percentage (\%) of agreement among the two analyses for each analyzed textbook

\begin{tabular}{|c|c|c|c|}
\cline { 2 - 3 } \multicolumn{1}{c|}{} & \multicolumn{2}{c|}{ Ratio Agreement (\%) } & \multirow{2}{*}{ Textbook } \\
\hline & $\begin{array}{c}\text { 1st-Analysis by } \\
\text { the 1st-Analyst }\end{array}$ & $\begin{array}{c}\text { 2nd-Analysis by the } \\
\text { 2nd-Analyst }\end{array}$ & \\
\hline MegaGoal4 & 94 & 91 & 92.5 \\
\hline MegaGoal5 & 92 & 85 & 88.5 \\
\hline MegaGoal6 & 88 & 87 & 87.5 \\
\hline
\end{tabular}

\subsection{Procedure and Processes of Analysis}

"The analysis of textbooks belongs to a class of non-reactive research technique called content analysis." (Al-Hadabi, 2007). Three main procedures (i.e. preparing the instrument of content analysis; coding; and analyzing the content of the textbooks.) were implemented to carry out content analysis. For preparing the instrument, four steps were conducted: to identify instrument's aim, instrument's validity, instrument's reliability, and instrument's content. Aim of the instrument was to analyze reading texts in the Saudi Student's Secondary School English Textbooks (i.e. MGSs). As for the rest three steps, they were explained earlier.

About to procedure of coding, it is so important to ease statistical analysis in analyzing data collected by content analysis from any texts (Wilson, 2011). "MGSs" was used as a code for the analyzed textbooks, and "Rs" was used as a code for the reading texts. MCs categories of THE INVENTORY'S LIFE SKILLS were also coded as follows: "MC1" for decision making, "MC2" for problem solving, "MC3" for, creating thinking, "MC4" for critical thinking, "MC5" for effective communication, "MC6 for social and interpersonal relationship, MC7 for self-awareness, MC8, for empathy, MC9 for coping with emotions, and MC10 for coping with stress. Likewise, SCs were coded as a SCs. They took cods from (SC1-SC25). Table (4) illustrates the codes of both MCs, and SCs of content analysis inventory.

Table 4. illustrates MCs and SCs of the content analysis inventory

\begin{tabular}{|c|c|}
\hline MC & SC \\
\hline \multirow{2}{*}{ Decision-making (MC1) } & assess available options (SC1) \\
\cline { 2 - 2 } & make a decision (SC2) \\
\hline \multirow{2}{*}{ Problem solving (MC2) } & perceive problems (SC3) \\
\cline { 2 - 2 } Creative Thinking (MC3) & Originality (SC5) \\
\cline { 2 - 2 } & Fluency (SC6) \\
\cline { 2 - 2 } & Flexibility (SC7) \\
\cline { 2 - 2 } & elaboration (SC8) \\
\cline { 2 - 2 } Critical Thinking (MC4) & classify and select data (SC) \\
\cline { 2 - 2 } & construct conclusion (SC10) \\
\cline { 2 - 2 } & judge conclusion (SC11) \\
\hline Effective Communication (MC5) & convince and motivate others (SC12) \\
\hline
\end{tabular}




\begin{tabular}{|c|c|}
\hline $\begin{array}{r}\text { ñllitg } \\
\text { Journal of Education } \\
\text { www.j } \\
\text { Volume (8) November } 20\end{array}$ & 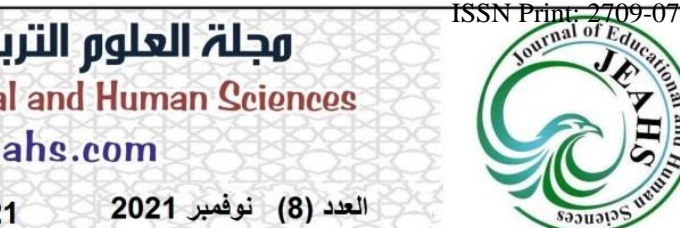 \\
\hline & convey information well (SC13) \\
\hline Social and Internersonal Relationshin (MC6) & social awareness (SC14) \\
\hline socral and mterpersonal kerationsmp (IVICo) & relationship management (SC15) \\
\hline \multirow{4}{*}{ Self-awareness (MC7) } & self-assessment (SC16) \\
\hline & self-reliance (SC17) \\
\hline & self-confidence (SC18) \\
\hline & set career path and goal (SC19) \\
\hline \multirow{2}{*}{ Empathy (MC8) } & understand others' feelings and thoughts (SC20) \\
\hline & responding others' needs (SC21) \\
\hline \multirow{2}{*}{ Coping with Emotions (MC9) } & realize one's own emotion (SC22) \\
\hline & self-management (SC23) \\
\hline \multirow{2}{*}{ Coping with Stress (MC10) } & recognize stress source (SC24) \\
\hline & managing stress (SC25) \\
\hline
\end{tabular}

\section{4. Analyzing Process}

Content analysis as methodology in social sciences for studying the content of communication, is considered a scholarly methodology in the humanities by which texts are studied in terms of authorship, authenticity or meaning. According to Weber (1990, p. 5) content analysis classifies textual material, reducing it to more relevant, manageable bits of data. content analysis allows for both quantitative and qualitative operations and also allows closeness to texts, which can alternate between specific categories and relationship and also statistically analysis the codes from the text (Ari, Dewi \& Diah, 2017, p. 90). As Pingel (1999, p.20), cited by Al-hadabi (2007, p. 102), suggested that

Every educational subject-oriented text can be analyzed from two general points of view: the didactic analysis deals with the methodological approach to the topic, exploring the pedagogy behind the text while the content analysis examines the text itself. What does the text tell us? Is it in accordance with academic research? Does it sufficiently cover the topic in question?

Therefore, for analyzing content of the reading texts in Saudi Student's Secondary School English Textbooks (i.e. MGSs), three processes were conducted for identifying population and sample, categories and unit, as well as setting up the instructions to achieve the procedures of content analysis. Three of the Saudi Student's Secondary School English Textbooks (i.e. MGSs) were identified as a population for this study that used to identify the sample of the study (i.e. 73 reading texts). Seventy-three reading texts were selected from the units of the Saudi Student's Secondary School English Textbooks (i.e. MGSs) to complete analyzing life skills in the analyzed textbooks.

As far the identifying Units analysis of content analysis, any expression or idea indicate specific life skills were used as a unit of analysis in this study. Therefore, "thematic unit" i.e. "an idea" was used as a "recording unit" and the "reading texts" was used as a "context unit". Consequently, the procedures for analyzing the 


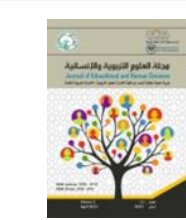

\section{مجلة العلوم التربوية والإنسانية}

Journal of Educational and Human Sciences

www.jeahs.com

Volume (8) November 2021

العدد (8) نوفمبر 2021

content of the Saudi Student's Secondary School English Textbooks (i.e. MGSs). Two units were also added to ease the counting of the frequencies: existing life skills, which were given the symbol $(\checkmark)$; and none existing was given the symbol (X).

Finally, a guide for analyzing the reading texts content of the Saudi Student's Secondary School English Textbooks (i.e. MGSs). This guide consists of the content analysis inventory's items, coding sheet and contents of the textbooks mentioned earlier. Content analysis began with a careful page-by-page analyzing these reading texts to find out the life skills selected for the content analysis. Excel software was used to keep track of what it was found.

\section{5. Statistical Analysis}

Suitable simple statistical analysis was used for analyzing collected data of this study (e.g., frequencies and percentages) to find out the availability MCs (MC1-MC10) and SCs (SC1-SC25) which integrated in the reading texts in each Saudi Student's Secondary School English Textbooks (i.e. MagGoal Series) of the $4^{\text {th }}$-grade up to the $6^{\text {th }}$-grade.

\section{Findings and Discussion}

Results of the study were set out according to its questions. As regard to the $1^{\text {st }}$ question "What are the life skills that supposed be included in the content of reading texts in the Saudi Student's Secondary School English Textbooks?", a total of (70) life skills were suggested to be a part of the Saudi Student's Secondary School English Textbooks' contents, as a result of the completely consensus among the panel of experts. These life skills distributed between (10) MCs and (25) SCs categories, as it is illustrated in table (4).

Relating the $2^{\text {nd }}$ question "What are the life skills included in the Saudi Student's Secondary School English Reading Textbooks for the $4^{\text {th }}$ grade up to the $6^{\text {th }}$-grade in terms of the supposed inventory?" To answer this question, three of the Saudi Student's Secondary School English Textbooks (i.e. MagGoal Series) of the $4^{\text {th }}$-grade up to $6^{\text {th }}$-grade were analyzed and the results were found as it is showed in table (5).

Table 5. The included MCs of Life Skills in the Saudi Student's Secondary School English Textbooks as a Whole

\begin{tabular}{|c|c|c|c|c|}
\hline $\mathbf{N}$ & $\mathbf{M C}$ & $\mathbf{F}$ & $\%$ & Order \\
\hline 1 & MC1 & 44 & 9.1 & $6^{\text {th }}$ \\
\hline 2 & MC2 & 34 & 7.0 & $8^{\text {th }}$ \\
\hline 3 & MC3 & 50 & 10.3 & $5^{\text {th }}$ \\
\hline 4 & MC4 & 55 & 11.3 & $3^{\text {rd }}$ \\
\hline 5 & MC5 & 51 & 10.5 & $4^{\text {th }}$ \\
\hline 6 & MC6 & 62 & 12.0 & $2^{\text {nd }}$ \\
\hline
\end{tabular}




\section{مجلة العلوم التربوية والإنسانية}

Journal of Educational and Human Sciences

www.jeahs.com

Volume (8) November 2021

العدد (8) نوفمبر 2021

\begin{tabular}{|c|c|c|c|c|}
\hline 7 & MC7 & 50 & 10.3 & $5^{\text {th }}$ \\
\hline 8 & MC8 & 77 & 15.9 & $1^{\text {st }}$ \\
\hline 9 & MC9 & 20 & 4.1 & $9^{\text {th }}$ \\
\hline 10 & MC10 & 42 & 8.7 & $7^{\text {th }}$ \\
\hline \multicolumn{2}{|c|}{ Total } & 485 & 100 & \multicolumn{1}{c}{} \\
\cline { 1 - 3 } & &
\end{tabular}

Table (5) shows that the highest score of the main categories was for MC8, empathy, which got frequencies of (77) and percentage of (15.9\%); MC6, Social and Interpersonal Relationship, that got frequency of (62) and percentage of (12.8\%); and MC3, critical thinking, with frequencies of (55) and percentage of $(11.3 \%)$. On the other hand, the lowest scores were MC9, coping with emotions, with frequencies of (20) and percentage of (4.1\%) and MC2, problem solving, with frequencies of (34) and percentage of (7.0\%).

The difference ratio between the highest and the lowest score (15.9\%$4.1 \%$ ) is evident. This indicates that imbalanced inclusion of MCs of life skills within the analyzed textbooks (i.e. Saudi Student's Secondary School English Textbooks). Despite of this vast difference, almost half of the ten specified MCs of LSs got nearly the expected percentage (10\%).

Table 6. Included Mcs of Life Skills in reading texts of Saudi Student's Secondary School English Textbooks for the $4^{\text {th }}$ Up to the $6^{\text {th }}$-Grades According to Inventory of the Life Skills

\begin{tabular}{|c|c|c|c|c|c|c|}
\cline { 2 - 7 } \multicolumn{1}{c|}{} & \multicolumn{2}{c|}{$\begin{array}{c}4^{\text {th }} \text {-MegGoal } \\
\text { textbook }\end{array}$} & \multicolumn{2}{c|}{$\begin{array}{c}5^{\text {th }} \text {-MegGoal } \\
\text { textbook }\end{array}$} & \multicolumn{2}{c|}{$\begin{array}{c}5^{\text {th }} \text {-MegGoal } \\
\text { textbook }\end{array}$} \\
\hline MC & $\mathbf{F}$ & $\mathbf{\%}$ & $\mathbf{F}$ & $\mathbf{\%}$ & $\mathbf{F}$ & $\mathbf{\%}$ \\
\hline MC1 & 26 & 13.7 & 30 & 17.5 & 21 & 16.9 \\
\hline MC2 & 25 & 13.2 & 27 & 15.8 & 10 & 8.1 \\
\hline MC3 & 13 & 6.8 & 26 & 15.2 & 16 & 12.9 \\
\hline MC4 & 22 & 11.6 & 20 & 11.7 & 9 & 7.3 \\
\hline MC5 & 12 & 6.3 & 19 & 11.1 & 19 & 15.3 \\
\hline MC6 & 21 & 11.1 & 21 & 12.3 & 8 & 6.5 \\
\hline MC7 & 26 & 13.7 & 8 & 4.7 & 10 & 8.1 \\
\hline MC8 & 18 & 9.5 & 7 & 4.1 & 17 & 13.7 \\
\hline MC9 & 17 & 8.9 & 9 & 5.3 & 8 & 6.5 \\
\hline MC10 & 10 & 5.3 & 4 & 2.3 & 6 & 4.8 \\
\hline Total & $\mathbf{1 9 0}$ & $\mathbf{1 0 0}$ & $\mathbf{1 7 1}$ & $\mathbf{1 0 0}$ & $\mathbf{1 2 4}$ & $\mathbf{1 0 0}$ \\
\hline
\end{tabular}

Table (6) shows that MCs of life skills were differently included in all of the analyzed textbooks and included within each textbook individually. Since the highest total number of MCs of life skills were for MGSs4 textbook (i.e. its frequencies were 190), while the lowest one was for MGSs6 textbook (i.e. its frequencies were 124). This implies that number of MCs of the life skills unexpectedly decreases as students move into advances educational stages, instead of increasing and improving. The table also shows unsystematic distribution each MC within these textbooks. On the other 


\section{مجلة العلوم التربوية والإنسانية}

Journal of Educational and Human Sciences

www.jeahs.com

Volume (8) November 2021

العدد (8) نوفمبر 2021

hand, MC1, Decision Making, was the highest frequencies (30) for MGSs5 textbook, while the lowest one was MC4, Critical Thinking, for MGSs6 textbook.

As for the $3^{\text {rd }}$ question, "Are there any differences between the analyzed textbooks in terms of the supposed inventory?". For the MCs of the life skills, table (7) shows the comparison of included them within the analyzed textbooks.

Table 7. comparison of included MCs of Life skills within the analyzed textbooks

\begin{tabular}{|c|c|c|c|c|c|c|}
\hline \multirow{2}{*}{ MC $^{1}$} & \multicolumn{2}{|c|}{$\begin{array}{c}4^{\text {th }} \text {-MegGoal } \\
\text { textbook }\end{array}$} & \multicolumn{2}{|c|}{$\begin{array}{c}5^{\text {th }} \text {-MegGoal } \\
\text { textbook }\end{array}$} & \multicolumn{2}{|c|}{$\begin{array}{c}6^{\text {th }} \text {-MegGoal } \\
\text { textbook }\end{array}$} \\
\cline { 2 - 7 } & Fs $^{2}$ & $\%$ & Fs & $\%$ & Fs & $\%$ \\
\hline MC1 & 26 & 13.17 & 30 & 17.5 & 21 & 16.9 \\
\hline MC2 & 25 & 13.2 & 27 & 15.8 & 10 & 8.1 \\
\hline MC3 & 13 & 6.8 & 26 & 15.2 & 16 & 12.9 \\
\hline MC4 & 22 & 11.6 & 20 & 11.7 & 9 & 7.3 \\
\hline MC5 & 12 & 6.1 & 19 & 11.1 & 19 & 15.3 \\
\hline MC6 & 21 & 11.1 & 21 & 12.3 & 8 & 6.5 \\
\hline MC7 & 26 & 13.7 & 8 & 4.7 & 10 & 8.1 \\
\hline MC8 & 18 & 9.5 & 7 & 4.1 & 17 & 13.7 \\
\hline MC9 & 17 & 8.9 & 9 & 5.3 & 8 & 6.5 \\
\hline MC10 & 10 & 5.3 & 4 & 2.3 & 6 & 4.8 \\
\hline 10 & 190 & 99.4 & 171 & 100 & 124 & 100 \\
\hline
\end{tabular}

As it is illustrated in table (7), all of the MCs were included in all of the analyzed MegGoal-textbook. But they were included in unbalanced way since the highest frequencies (190) of the included MCs were for the lowest grade (i.e. $4^{\text {th }}$-grade textbook), while the lowest frequencies (124) were for the highest grade (i.e. the $6^{\text {th }}$-grade textbook). On the contrarily, the highest MCs were supposedly included in the highest grade and vice versa, to meet the gradation principle in terms of the depth of knowledge.

According to the $4^{\text {th }}$-MegGoal textbook, both MC7, Self-Awareness, and MC1, Decision Making, were the highest frequencies, since each of them got (26 frequencies). On the other hand, the lowest frequencies were (10 frequencies) for MC10, Coping with Stress. As for the $5^{\text {th }}$-MegGoal textbook, the highest frequencies were (30) for MC1, Decision Making, and the lowest frequencies were (4) for MC10. Likewise, MC1 got the highest frequencies (21) and the lowest frequencies were (6) also for MC10, as regard to the $6^{\text {th }}$-MegGoal textbook.

${ }^{1} \mathrm{MC}=$ Main Category

${ }^{2} \mathrm{Fs}=$ Frequencies 


\section{مجلة العلوم التربوية والإنسانية}

Journal of Educational and Human Sciences

www.jeahs.com

Volume (8) November 2021

العدد (8) نوفمبر 2021

Table 8. Comparison of Included SCs of Life Skills within the Analyzed Textbooks

\begin{tabular}{|c|c|c|c|c|c|c|}
\hline \multirow{2}{*}{ SC $^{3}$} & \multicolumn{2}{|c|}{$\begin{array}{c}4^{\text {th }} \text {-MegGoal } \\
\text { textbook }\end{array}$} & \multicolumn{2}{c|}{$\begin{array}{c}5^{\text {th }} \text {-MegGoal } \\
\text { textbook }\end{array}$} & \multicolumn{2}{c|}{$6^{\text {th }}$-MegGoal } \\
& Fs & $\%$ & Fs & $\%$ & Fs & $\%$ \\
\cline { 2 - 7 } SC1 & 12 & 6.3 & 5 & 2.9 & 3 & 2.4 \\
\hline SC2 & 14 & 7.4 & 3 & 1.8 & 7 & 5.6 \\
\hline SC3 & 14 & 7.4 & 3 & 1.8 & 4 & 3.2 \\
\hline SC4 & 3 & 1.6 & 6 & 3.5 & 4 & 3.2 \\
\hline SC5 & 1 & 0.5 & 6 & 3.5 & 7 & 5.6 \\
\hline SC6 & 2 & 1.1 & 3 & 1.8 & 1 & 0.8 \\
\hline SC7 & 5 & 2.6 & 8 & 4.7 & 8 & 6.5 \\
\hline SC8 & 4 & 2.1 & 2 & 1.2 & 3 & 2.4 \\
\hline SC9 & 5 & 2.6 & 13 & 7.6 & 6 & 4.8 \\
\hline SC10 & 5 & 2.6 & 7 & 4.1 & 4 & 3.2 \\
\hline SC11 & 3 & 1.6 & 6 & 3.5 & 6 & 4.8 \\
\hline SC12 & 16 & 12.9 & 10 & 5.8 & 1 & 0.8 \\
\hline SC13 & 6 & 3.2 & 10 & 5.8 & 8 & 6.5 \\
\hline SC14 & 14 & 11.7 & 11 & 6.4 & 4 & 3.2 \\
\hline SC15 & 11 & 5.8 & 16 & 9.4 & 6 & 4.8 \\
\hline SC16 & 9 & 4.7 & 1 & 0.6 & 6 & 4.8 \\
\hline SC17 & 6 & 3.2 & 14 & 8.2 & 2 & 1.6 \\
\hline SC18 & 2 & 1.1 & 4 & 2.3 & 0 & 0.0 \\
\hline SC19 & 4 & 2.1 & 2 & 1.2 & 0 & 0.0 \\
\hline SC20 & 13 & 6.8 & 18 & 14.1 & 16 & 12.9 \\
\hline SC21 & 13 & 6.8 & 12 & 7.0 & 5 & 4.0 \\
\hline SC22 & 7 & 5.9 & 2 & 1.2 & 4 & 3.2 \\
\hline SC23 & 3 & 1.6 & 2 & 1.2 & 2 & 1.6 \\
\hline SC24 & 3 & 1.6 & 5 & 2.9 & 15 & 12.1 \\
\hline SC25 & 15 & 7.9 & 2 & 1.2 & 2 & 1.6 \\
\hline 25 & 190 & 100 & 181 & 100 & 124 & 100 \\
\hline & & & & & & \\
\hline
\end{tabular}

Table (8) shows that all of the SCs were included in each analyzed textbooks. For the $4^{\text {th }}$-MegGoal textbook, the range of $\mathrm{SCs}^{\prime}$ inclusion was from $1(0.5 \%)$ for SC5, creative thinking, to $16(12.9 \%)$ for $\mathrm{SC} 12$, convince and motivate others. As for the $5^{\text {th }}$-MegGoal textbook, the range of SCs' incorporation was from $1(0.6 \%)$ for SC16, Self-assessment, to $16(9.4 \%)$ SC15 (i.e. Relationship Management).

\section{Conclusion}

Throughout the world, life skills become indispensable competencies for everyone because of their cultural norms, to cope with demands and challenges of their daily life. Most educational systems around the world are vastly trend to reorganize the content of educational programs to improve 


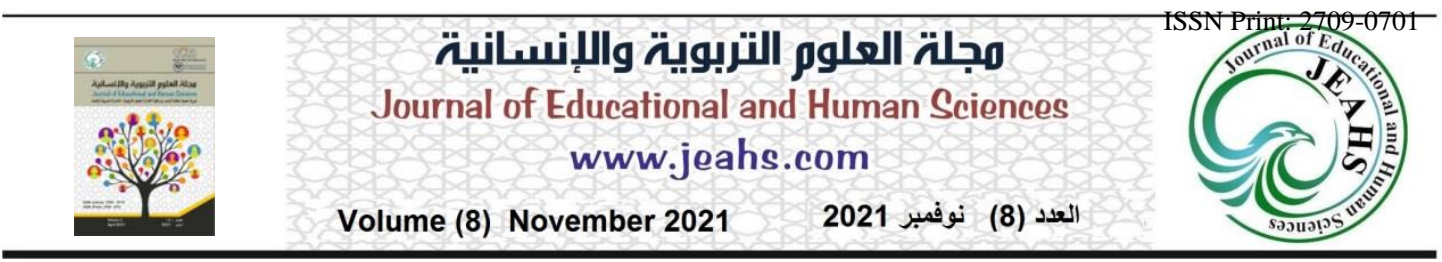

high school students' life skills. So, inclusion life skills to the Saudi Student's Secondary School English Textbooks, MGSs textbooks, is a recent strategic plan to prepare students for encountering the multifaceted and complex life situations. Yet, the purpose of this study was at finding out the integrated life skills in the Saudi Student's Secondary School English Textbooks, MGSs textbooks, for the $4^{\text {th }}$-grade up to the $6^{\text {th }}$-grade. Specifically, this study attempted to answer the following questions:

1. What are the life skills that supposed be included in the content of the Saudi Student's Secondary School English Textbooks?

2. What are the included life skills in the Saudi Student's Secondary School English Textbooks for the $4^{\text {th }}$ up to the 6th-grades in terms of the inventory's life skills?

3. Are there any differences between the analyzed textbooks in terms of the supposed inventory?

Based on the relevant literature review, inventory of the life skills and checklist for content analysis were developed. The checklist was used to analyze a sample consisted of 73 reading texts, which were selected from a population of the Saudi Student's Secondary School English Textbooks (i.e. 3 MGSs-textbooks). Results of the study indicated that the analyzed textbooks (i.e. In Saudi Student's Secondary School English Textbooks, MGSstextbooks) contained all inventory's life skills.

\section{Recommendations}

If we believe that the most important objective of education is the socialization and behavioral transformations in students, the system of education needs to enrich the curriculum with well-designed textbooks and adequate support materials to enhance effective implementation and imparting of life skills, since students learn more through interaction with learning materials. At level of planning and development of life skills should be included in the statement of objectives of English language teaching courses. School textbooks authors and editors should focus on selecting texts that are conducive to the practice and reinforcement of life skills. Moreover, through and extensive reviews of curriculum and textbooks analysis with respect to inclusion of life skills to the maximum impact should be conducted continually.

\section{References}

1. Abu Saib, M. K., \& Al-Hadidi, M. (2018). The Degree Life Skills Are Included in the English Language Curriculum for Sixth Grade Students in Amman and the Degree these Skills Are Acquired by Students as Perceived by their Teachers. Studies of Educational Sciences, Proceedings of the Conference of the College of Educational Sciences: Education in the Arab World Towards a Distinguished Educational System, 


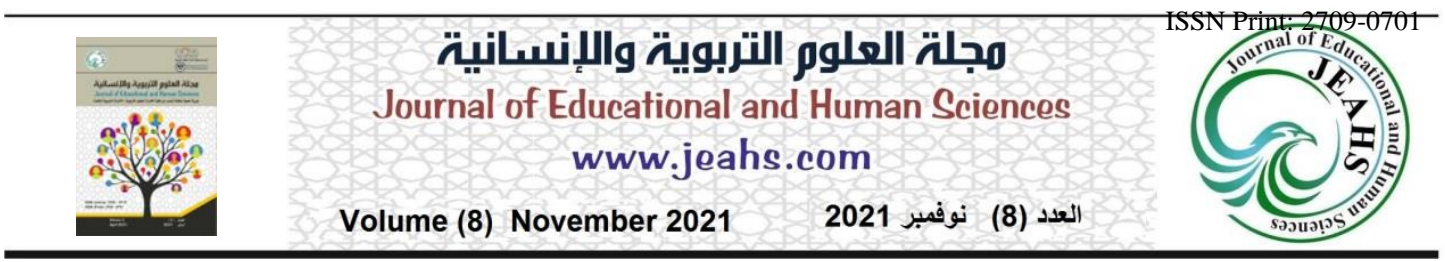

45(3), 370-388.

2. Al-Hadabi, A., S., S., D. (2007). Analysis of The Environmental Concepts in Science Textbooks of the Basic Education Stage in The Republic of Yemen. PhD Thesis. University of UKM, Malysia.

3. Al-Mamary, S., A. (2018) Acquisition Level of Life Skills by Level Four Students and its Relationship with the Students' Application of those Skills during Practicum. Journal of Educational and psychological Sciences, 3(19), 400-428.

4. Aparna, N., \& Raakhee, A. S. (2011). Life Skill Education for Adolescents: its Relevance and Importance. Journal of Education Sciences and Psychology, 2(19), 3-7 ISSN 1512-1801 5

5. Ari, P., Dewi, R., \& Diah, K. (2017). A Content Analysis of Bright 1: A 2013 Curriculum-Based Textbook for VII Grade Students. Advances In Social Science, Education and Humanities Research (ASSEHR), 158, 89-100.

6. Ashraf, H., Jadidolesam. M. R., \& Jan-nesar. Q. (2017, November 21-23). Life Skills in Iranian EFL Textbooks: A Mixed Method. A research submitted to the 15th International TELLSI Conference, Islamic Azad University, Roudehen Branch, Tehran, Iran.

7. Bailey, S., \& Deen, M. (2002). Development of a Web-Based Evaluation System: A Tool for Measuring Life Skills in Youth and Family Programs. Family Relations, 51(2), 138-147

8. Bouzid, H. A. (2016). Boosting the 21st Century Skills through Moroccan ELT Textbooks. Journal of English Language Teaching and Linguistics (JELTL), 1(1), 97108.

9. Erawan, P. (2010). Developing Life Skills Scale for High School Students through Mixed Methods Research. European Journal of Scientific Research, 47(2), 169-186. Retrieved from: http://www.eurojournals.com/ejsr.htm

10. Esmaeilinasab, M., \& Davoud, M. M. (2011). Effectiveness of Life Skills Training on Increasing Self-esteem of High School Students. Procedia-Social and Behavioral Sciences, 30, 1043-1047. DOI: 10.1016/j.sbspro.2011.10.203

11. Gayatri, MSW. Channaveer, RM., \& Lakshmana, G. (2017). Life skills education program among high school children: An intervention study. Journal of Mental Health Education, 1 (1), 19-29. Retrieved from:

12. file:///C:/Users/User/Downloads/Life\%20skills\%20final\%20(3).pdf

13. Al-Ghazo, A. \& Samadi, O. M. (2013). A Content Analysis of the English Reading Texts Authenticity in Student's Book of Action Pack Eleven in Jordan. European Scientific Journal, 9(29), 345-359.

14. Giri, D., \& Sharma, J. (2016: February). Promotion of Life Skills Education for Adolescents. A research submitted to International Conference: Science of Human Learning. New Delhi volume 2

15. Haji, T. M., Mohannadkhani, S. \& Hahtami, M. (2011). The Effectiveness of Life Skills Training on Happiness, Quality of Life and Emotion Regulation. ProcediaSocial and Behaviral Sciences, 30, 407-411.

16. Hamodona, Y.O. (2007). Life Skills in the Content of English for Palestine- 


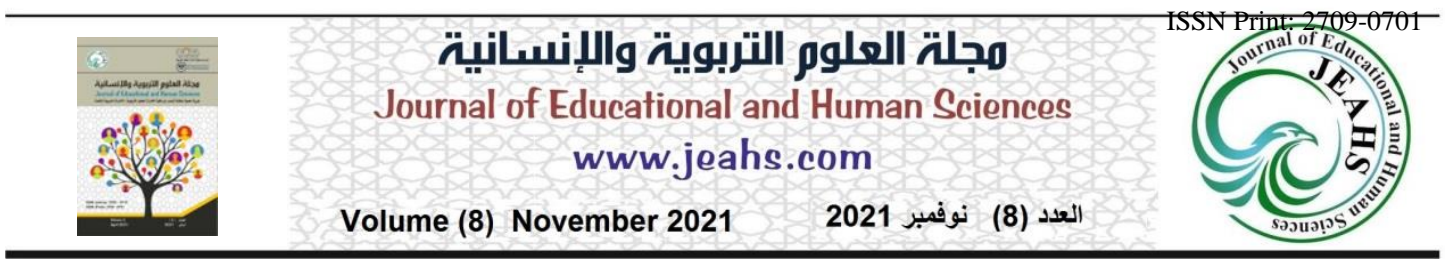

Grade Six Textbook. (Unpublished Master's Thesis). The Islamic University of Gaza, Palestine. Retrieved from https://library.iugaza.edu.ps/Thesis/74439.pdf

17. Hsieh, H., Shannon, S. E. (2005). Three Approaches to Qualitative Content Analysis. Qual Health Res, 15(9), 1277-1288.

18. Incebacak, B. B. \& Erosy, E. (2018). Problem Solving of Secondary School Students. China-USA Business Review, 15(6), 275-285.

19. Instructional Services-Textbook Adoptions Office. (2004). Invitation to Submit Textbooks for Evaluation and Adoption in North Carolina. North Carolina.

20. Khosravani, M., Motallebzadeh, K., \& Ashraf, H. (2014). Designing a ' Life Skills Questionnaire" for analyzing the Socio-cultural Constructs of EFL Textbooks. The International Jouranl of Language Learning and Applied Linguistics World (IJLLALW), 5(2), 200-207.

21. Khosravani, M., Khosravani, M., \& Khorashadyzadeh, A. (2014). Analyzing the Effects of Iranian EFL Textbooks on Developing Learners' Life Skills. English Language Teaching, 7(6), 54-67.

22. Kumar, J., \& Chhabra, A. (2014). Life Skill Education for Adolescents: Coping with Challenges. Scholarly Research Journal for Humanity Science \& English Language, 1(2), 181-190.

23. Lagat, G. (2017). Life Skills Education Curriculum Implementation: Appropriateness of Teaching Methodologies Used by Secondary School Teachers In Usain Gishu Country, Kenya. International Journal of Education, Learning and Development, 5(4), 86-95.

24. Lavallee, D., \& Jones, M. I. (2009). Explorign the Life Skills needs of British adolescent athletes. Psychology of Sport and Exercise, 10,159-167.

25. Allehyani, B., Burnapp, D., \& Wilson, J. (2017). The Place of Inner-Circle Culture in Saudi Secondary School Textbooks. International Journal of English and Education, 6(2), 11-21.

26. Al-Masri, A., Smadi, M., Aqel, A., \&Hamed, W. (2016). The Inclusion of Life Skills in English Textbooks in Jordan. Journal of Education and Practice, 7(16), 8196.

27. Ministry of Education (MOE). (2018). Secondary education guide, curriculum system, first edition. Ministry of Education Agency, Curriculum System Unit.

28. Mostafa, R. A., Dadour, E. M., \& Al-Shafei, A. I. (2016). Developing Life Skills in the Egyptian Curriculum at Primary Stage. Journal of Research in Curriculum, Instruction and Educational Technology, 2(1), 43-62,

29. Mugami, M., \& Muthui, R. (2013). Influence of Structural Context on Implementation of Secondary School Life Skills Curriculum in Kajiado Country, Kenya. International Journal of Education and Research, 1(30), 1-22.

30. Munsi, K.\& Guha, D. (2014). Status of life skills education in teacher education curriculum of SAARC countries: A comparative evaluation. Journal of Education \& Social Policy, 1(1),93-99.

31. Okeefee, L. (2013). A Framework for Textbook Analysis. International Review of Contemporary Learning Research, 2(1), 1-13. 


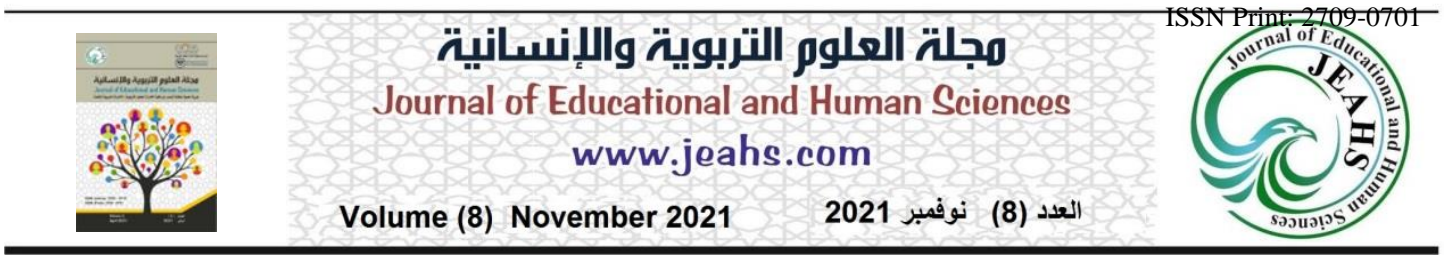

32. Panduranga, S. N., Madkhali, A., Wasli, S., Daghriry, A. , \& Abdullah, F. (2018). Empowering Saudi EFL Learners with Life Skills- The Need of the Hour. International Journal of Science and Research,8(5), 383- 850.

33. Pingel, F. 1999. UNESCO guidebook on textbook research and textbook revision. Paris: UNESCO, Braunschweig: Georg Eckert Institute for International Textbook Research.

34. Rakhmawati, D. M., \& Priyana, J. (2019). A Study on 21st Century Skills Integration in the English Textbook for Senior High School. Journal of English Educators Society, 4 (1), 9-16.

35. Ratka, A. (2018). Empathy and the Development of Affective Skills. American Journal of Pharmaceutical Education, 82(10), 1140-1143.

36. Richards, J. (2001) Curriculum Development in Language Teaching. Cambridge University Press. New York, USA.

37. Rinekso, A. B. (2021). The Representation of 21st Century Skills in an Indonesian EFL Textbook. LLT Journal, 24 (1), 191-211.

38. Sajid, N. J. , Saleh, M., \& Retmono. (2013). Integrating Life Skills in English Language Teaching (ELT): Strategies, Problems and their Possible Solutions. LANGUAGE CIRCLE Journal of Language and Literature, 7(2), 75-91.

39. Shahmohammadi, N. (2013). Content Analysis of Elementary Science Text Book Based on the Achievement Motivation Constructs. Procedia- Social and Behavioral Sciences, 84, 426-430.

40. Alshumaimeri, Y. A. (2015). Using Material Authenticity in the Saudi English Textbook Design: A Content Analysis from the Viewpoints of EFL Teachers. Australian International Academic Centre, 6(2), 229-240.

41. Sing, M., \& Sing, N. (2014). An Analytical Study of English and Hindi Language Textbooks of Clsdd-IX U. P. Board in Perspective of Life Skills. IOSR Journal of Research \& Method in Education, 4(1), 23-26.

42. Sing, H., \& Gera, M. (2015). Stratiges for Development of Life Skills anf Global Competencies. International Journal of Scientific Research, 4(6),760-763.

43. Strikala, B., \& Kishore, K. ( 2010). Empowering Adolescent with Life Skills Education in Shool-School Mental Health Program: Does it work? Indian J Psychiatry, 52(4), 344-349.

44. Al-Tamimi, R. (2019). Policies and Issues in Teaching English to Arab EFL Learners: A Saudi Arabian Perspective. Arab World English Journal (AWEJ), 10(2), 68-76.

45. United Nations Children's Fund (UNICEF). (2019). Comprehensive Life Skills Framework: Rights based and life cycle approach to building skills for empowerment. Retrieved from: https://www.unicef.org/india/sites/unicef.org.india/files/202002/Comprehensive-lifeskills-framework.pdf

46. Valverde, G. and L. Bianchi and R. Wolfe and W. Schmidt and R. Houang, (2002), According to the Book: Using TIMSS to Investigate the Translation of Policy into Practice through the World of Textbooks, London: Kluwer Academic Publishers. Retrieved from: https://www.springer.com/gp/book/9781402010330 


\section{مجلة العلوم التربوية والإنسانية \\ Journal of Educational and Human Sciences \\ www.jeahs.com \\ Volume (8) November 2021 \\ العدد (8) نوفمبر 2021}

47. Weber, R. P. (1990). Basic Content Analysis (2nd ed.). Sage Publications, Newbury Park, CA.

48. World Health Organization (WHO) (1997). Life Skills Education for Children in schools: Introduction and Guidelines to facilitate the development and implementation of life skills programme. Geneva, World Health Organization.

49. World Health Organization (WHO) (2020). Life Skills Education Schools: Handbook: Prevention of Noncommunicable Diseases. Geneva, World Health Organization.

https://www.who.int/publications/i/item/9789240005020

50. Wilson, V. (2011). Research Method: Content Analysis. Evidence Based Library and Information Practice,6 (4), 177- 179. 